\title{
Expansion of acquired 16S rRNA methytransferases along with CTX-M-15, NDM and OXA-48 within three sequence types of Escherichia coli from northeast India
}

Jayalaxmi Wangkheimayum', Mohana Bhattacharjee', Bhaskar Jyoti Das', K. Melson Singha², Debadatta Dhar Chanda ${ }^{2}$ and Amitabha Bhattacharjee ${ }^{* *}$ (D)

\begin{abstract}
Background: This study aimed to identify ten different $16 \mathrm{~S} r R N A$ methyltransferase genes $(r m t A, r m t B, r m t C, r m t D$, $\operatorname{armA}, r m t F, n p m A, r m t H, r m t E$ and $r m t G)$ and their coexisting ESBL and carbapenemase with the emergence of three E.coli clones within a single study centre.

Methods: A total of 329 non-duplicate E.coli isolates were studied to detect the presence of $16 \mathrm{~S}$ rRNA methyltransferases along with $\beta$-lactamases (TEM, SHV, OXA, VEB, GES, PER,CTX-M types, NDM, OXA-48,VIM, IMP and KPC) using PCR assay. Horizontal transferability were validated by transformation and conjugation analysis. Plasmid incompatibility typing and MLST analysis was also performed.

Results: A total of 117 isolates were found to be resistant to at least one of the aminoglycoside antibiotics. It was observed that 77 (65.8\%) were positive for $16 \mathrm{~S}$ rRNA methyltransferases. Among them thirty nine isolates were found to harbour only bla $a_{\mathrm{CTX}-\mathrm{M}-15}$, whereas combination of genes were observed in three isolates $\left(b a_{V E B}+b a_{C T X-M-15}\right.$ in 2 isolates and bla $a_{\text {PER }}+$ bla $a_{\mathrm{CTX}-\mathrm{M}-15}$ in 1 isolate). bla $a_{\mathrm{NDM}}$ and bla $a_{\mathrm{OXA}-48}$ like genes were found in 23 and 9 isolates, respectively. All the resistance genes were conjugatively transferable, and incompatibility typing showed multiple $16 \mathrm{~S}$ rRNA methyltransferase genes were originated from a single Inc. 11 group. MLST analysis detected 3 clones of E.coliST4410, ST1341 and ST3906.

Conclusion: The present study identified emergence of three clones of E.coli, resistant to aminoglycoside -cephalosporincarbapenem. This warrants immediate measures to trace their transmission dynamics in order to slow down their spread in clinical setting.
\end{abstract}

Keywords: 165 rRNA methyltranseferase, CTX-M-15, NDM, OXA-48, Aminoglycoside, E.coli

\footnotetext{
* Correspondence: ab0404@gmail.com

${ }^{1}$ Department of Microbiology, Assam University Silchar, Silchar, India

Full list of author information is available at the end of the article
}

(c) The Author(s). 2020, corrected publication 2020. Open Access This article is licensed under a Creative Commons Attribution 4.0 International License, which permits use, sharing, adaptation, distribution and reproduction in any medium or format, as long as you give appropriate credit to the original author(s) and the source, provide a link to the Creative Commons licence, and indicate if changes were made. The images or other third party material in this article are included in the article's Creative Commons licence, unless indicated otherwise in a credit line to the material. If material is not included in the article's Creative Commons licence and your intended use is not permitted by statutory regulation or exceeds the permitted use, you will need to obtain permission directly from the copyright holder. To view a copy of this licence, visit http://creativecommons.org/ licenses/by/4.0/. The Creative Commons Public Domain Dedication waiver (http://creativecommons.org/publicdomain/zero/1. 0/) applies to the data made available in this article, unless otherwise stated in a credit line to the data. 


\section{Background}

Aminoglycoside antibiotics have a wide spectrum of activity against both Gram positive and Gram negative bacteria and are used in combination with $\beta$-lactam antibiotics, especially third generation cephalosporins. However, emergence of multidrug resistance severely compromised this therapeutic option as organisms harbour multiple resistance determinants to make chemotherapeutic alternatives ineffective. 16S rRNA methylation is one of the major mechanisms of aminoglycoside resistance [1]. In India there are multiple reports of $16 \mathrm{~S}$ rRNAmethyltrasferase genes (armA,rmtA, rmtB, rmtC, rmtD and $r m t F)$ as published in various studies [2-4]. These enzymes are responsible for alteration of A site of $16 \mathrm{~S}$ rRNA and reported across the globe [5-10]. These genes are often associated with horizontal transmission and expansion of aminoglycoside resistance in hospital settings along with other resistance determinants [11]. These 16S rRNA methyl transferases confer resistance to all clinically relevant aminoglycosides and in particular high level resistance to amikacin. In the present study we have investigated the presence of acquired $16 \mathrm{~s}$ rRNA rmehyltransferase genes along with other co-resistance determinants in the clinical isolate of $E$. coli in a tertiary referral hospital of northeastern part of India.

\section{Methods}

\section{Bacterial strains}

A total of 329 consecutive clinical isolates of Escherichia coli were obtained from Silchar Medical College and Hospital, India, during March 2018-February 2019 from the patients who were admitted or attended the clinic and associated with infection. The additional information of the isolates was presented in supplementary Table S1. Isolates were identified by VITEK $^{\oplus} 2$ compact system (Biomeriux, USA). The study was approved by Institutional ethical committee of both Silchar Medical College and Assam University,

\section{Antimicrobial susceptibility testing}

Minimum inhibitory concentration (MICs) of isolates against aminoglycoside antibiotics namely; kanamycin, tobramycin, gentamicin, netilmicin, amikacin and streptomycin (Hi,Media,India) were determined by agar dilution method. Disc diffusion method was used for detection of susceptibility pattern towards imipenem $(10 \mu \mathrm{g})$, meropenem $(10 \mu \mathrm{g})$, cefepime $(30 \mu \mathrm{g})$, aztreonam $(30 \mu \mathrm{g})$ cefotaxime $(30 \mu \mathrm{g})$, ceftazidime $(30 \mu \mathrm{g})$, ceftriaxone $(30 \mu \mathrm{g})$ and ciprofloxacin $(5 \mu \mathrm{g})$. E. coli ATCC 25922 was used as control. Results were interpreted in accordance with Clinical and Laboratory Standards Institute (CLSI) guidelines 2017 [12].

\section{Molecular characterization of 16S rRNA methyltransferase genes}

The isolates which were resistant to at least one of the aminoglycoside antibiotics tested were subjected to PCR assay targeting $16 \mathrm{~S}$ rRNA methyl transferase genes namely; $r m t A, r m t B, r m t C, r m t D, r m t E, r m t F, r m t G$ rmt $H$ arm $A$ and npmA (Table 1). The PCR mixture composed of $12.5 \mu \mathrm{l}$ Go Taq green Master mix (Promega, Madison, USA) $10 \mathrm{pmol}$ of each primer and $100 \mathrm{ng}$ DNA template prepared by boiling centrifugation method $\left(83^{\circ} \mathrm{C}\right.$ for $\left.20 \mathrm{mins}\right)$. The PCR was conducted in BioRadT100 $100^{\text {Tw }}$ Thermal cycler with the conditions: Initial denaturation at $95^{\circ} \mathrm{C}$ for $5 \mathrm{~min}, 32$ cycles of denaturation at $95^{\circ} \mathrm{C}$ for $30 \mathrm{~s}$, annealing at $50^{\circ} \mathrm{C}$ for $40 \mathrm{~s}$, extension at $72{ }^{\circ} \mathrm{C}$ for $40 \mathrm{~s}$ and final extension at $72{ }^{\circ} \mathrm{C}$ for $7 \mathrm{~min}$.

\section{Determination of co-existing ESBLs and carbapenemases} Further, all the $16 \mathrm{~S}$ rRNA methyltransferase producing isolates were subjected to detection of ESBLs and carbapenemases. ESBL production was confirmed among by phenotypic screening containing $1 \mu \mathrm{g} / \mathrm{ml}$ of cefotaxime and ceftazidime followed by combined disc diffusion test as per CLSI guidelines (2017). PCR assay was carried out with primers specific for several commonly occurring beta - lactamases genes viz.; bla ${ }_{\mathrm{TEM}}$, bla $\mathrm{SHV}$, bla OXA,

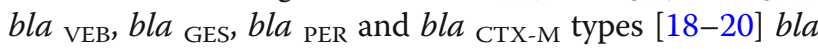
NDM [21], bla OXA-48, bla VIM, bla IMP and bla KPC [22]. Two separate multiplex PCR assays were performed. Reactions were run under the following conditions: initial denaturation at $95{ }^{\circ} \mathrm{C}$ for $5 \mathrm{~min}$; 32 cycles of $95{ }^{\circ} \mathrm{C}$ for 1 min, $54{ }^{\circ} \mathrm{C}$ for $1 \mathrm{~min}$ and $72{ }^{\circ} \mathrm{C}$ for $1 \mathrm{~min}$; and a final elongation at $72{ }^{\circ} \mathrm{C}$ for $7 \mathrm{~min}$. The amplicons of the reaction with $b l a_{\mathrm{CTX}-\mathrm{M}}$ primers were further sequenced to identify the exact variant.

\section{Horizontal transferability assay}

Total Plasmid content was extracted by QIAprep Spin Miniprep Kit (Qiagen, Germany) and isolated plasmids were subjected to transformation by heat shock method using Escherichia coli DH5 $\alpha$ as recipient. Transformants were selected on to the Luria Bertani agar (Hi-Media, Mumbai,India) containing $2 \mu \mathrm{g} / \mathrm{ml}$ of kanamycin. Conjugation assay was performed where the isolates harbouring $16 \mathrm{~S}$ rRNA methyltransferase genes, acted as donor and azide resistant E.coli J53 was used as recipient. Mating was performed where both the donor and recipient cells were cultured in LB broth (Hi-Media) till it attained optical density at $600 \mathrm{~nm}\left(\mathrm{OD}_{600}\right)$ of $0.8-0.9$. Cells were mixed at a ratio of 1:5 donor-to-recipient and transconjugant was selected on LB medium (Hi Media,Mumbai, India) containing $2 \mu \mathrm{g} / \mathrm{ml}$ of kanamycin and $100 \mu \mathrm{g} / \mathrm{ml}$ of sodium azide. Transformants and transconjugants were further screened for the presence of $16 \mathrm{~S}$ 
Table 1 Primers used in this study for amplification of 165 rRNAmethyltransferase genes

\begin{tabular}{|c|c|c|c|}
\hline $\begin{array}{l}\text { Target } \\
\text { primers }\end{array}$ & Sequence (Forward\& reverse-5'-3') & $\begin{array}{l}\text { Amplicon } \\
\text { size (bp) }\end{array}$ & Reference \\
\hline \multirow[t]{2}{*}{$\operatorname{armA}$} & GGTGCGAAAACAGTCGTAGT & 1153 & [22] \\
\hline & TCCTCAAATATCCTCTATGT & & \\
\hline \multirow[t]{2}{*}{$r m t A$} & CTAGCGTCCATCCTITCCTC & 635 & [22] \\
\hline & TाTGCTTCCATGCCCTTGCC & & \\
\hline \multirow[t]{2}{*}{$r m t B$} & GGAATTCCATATGAACATCAACGATGCC & 756 & [22] \\
\hline & CCGCTCGAGTCCATTCTITITTATCAAGT & & \\
\hline \multirow[t]{2}{*}{ rmtC } & CGAAGAAGTAACAGCCAAAG & 1000 & [22] \\
\hline & GCTAGAGTCAAGCCAGAAAA & & \\
\hline \multirow[t]{2}{*}{$r m t D$} & TCATTTCGTTCAGCAC & 744 & [22] \\
\hline & AAACATGAGCGAACTGAAGG & & \\
\hline \multirow[t]{2}{*}{ npmA } & CGGGATCCAAGCACTTTCATACTGACG & 981 & [22] \\
\hline & CGGAATTCCAATTTTGTTCTTATTAGC & & \\
\hline \multirow[t]{2}{*}{$r m t E$} & ATGAATATTGATGAAATGGTTGC & 818 & [23] \\
\hline & TGATTGATTCCTCCGTITTG & & \\
\hline \multirow[t]{2}{*}{$r m t F$} & GCGATACAGAAAACCGAAGG & 589 & [24] \\
\hline & ACCAGTCGGCATAGTGCTTT & & \\
\hline \multirow[t]{2}{*}{$r m t G$} & AAATACCGCGATGTGTGTCC & 250 & [25] \\
\hline & ACACGGCATCTGTTTCTTCC & & \\
\hline \multirow[t]{2}{*}{$r m t H$} & AATGACCATTGAACAGGCAGC & 760 & [26] \\
\hline & TCAAGCTGGGTTTGGCTGGA & & \\
\hline
\end{tabular}

methyltransferase genes, ESBLs and carbapenemase genes as obtained in parent isolates.

\section{Plasmid incompatibility typing}

All the transformants and transconjugants were selected for this experiment. Plasmids were characterized by PCR-based replicon typing (PBRT) to identify the different incompatibility (Inc.) types. PBRT targeted 18 different replicon types viz. FIA, FIB, FIC, HI1, HI2, I1-Iy, L/ $\mathrm{M}, \mathrm{N}, \mathrm{P}, \mathrm{W}, \mathrm{T}, \mathrm{A} / \mathrm{C}, \mathrm{K}, \mathrm{B} / \mathrm{O}, \mathrm{X}, \mathrm{Y}, \mathrm{F}$, and FIIA performing 5 multiplex PCR and 3 simplex PCR [23].

\section{Multilocus sequence typing (MLST)}

Multilocus sequence typing (MLST) was carried out for all $16 \mathrm{~S}$ rRNA methyl transferase producing E.coli using the protocols and conditions described on the E. coli MLST website (http://mlst.warwick.ac.uk/mlst/dbs/Ecoli/ documents/primersColi-html). Sequence types were determined after analysing by using centre for genomic epidemiology MLST analysis tool (https://cge.cbs.dtu.dk/ services/MLST/).

\section{Results}

Antimicrobial susceptibility testing showed that majority of the isolates were susceptible to meropenem (296/329) followed by imipenem (293/329), cefepime (282/329) aztreonam (281/329), ceftazidime (279/329), cefotaxime (276/329) and ceftriaxone (276.329) whereas ciprofloxacin showed moderate activity (165/329). Among them, a total of 117 isolates were found to be resistant to at least one of the aminoglycoside antibiotics viz.; gentamicin, tobramycin, amikacin, netilmicin and kanamycin.

\section{Detection of 16S rRNA methyltransferase genes}

Of 117 isolates, it was observed that 77 (65.8\%) were positive for $16 \mathrm{~S}$ rRNA methyltransferase genes. Among them, isolates harbouring $\operatorname{rmt} C(n=12)$ were more in numbers followed by $\operatorname{armA}(n=11), \operatorname{rmtD}(n=9), \operatorname{rmt} F(n=8)$, $\operatorname{rmtB}(n=6), n p m A(n=5), \operatorname{rmtH}(n=4), \operatorname{rmtE}(n=1)$ and rmtG $(n=1)$. Combination of multiples genes were also observed in some isolates. These were as; $\operatorname{arm} A+r m t F$ $(n=3), r m t G+r m t H(n=3), \operatorname{arm} A+\operatorname{rmtF}(n=3), \operatorname{arm} A+$ $r m t E(n=3), \operatorname{rmt} C+\operatorname{rmtD}(n=3), \operatorname{arm} A+\operatorname{rmt} A(n=2)$ and $\operatorname{arm} A+r m t F+r m t C+r m t D(n=3)$. The details of their distribution is given in Table 2.

\section{Co-existing ESBLs and Carbapenemases}

Among the 16S RMTases producing isolates 42 of them were confirmed to be ESBL positive by phenotypic methods as thirty nine of them were harbouring only $b l a_{\mathrm{CTX}-\mathrm{M}-15}$ and a combination of $b l a_{\mathrm{VEB}}+b l a_{\mathrm{CTX}-\mathrm{M}-15}$ and $b l a_{\mathrm{PER}}+b l a_{\mathrm{CTX}-\mathrm{M}}$ was observed in two and in a single isolate respectively. Twenty three of them were $b l a_{\mathrm{NDM}}$ positive and 9 isolates harboured OXA-48 like genes (Table 2).

\section{Horizontal transferability}

All the resistance genes detected were conjugatively transferable and transformants carrying the 16SrRNAmethyl transferase genes along with ESBLs and carbapenemases could be selected in the media containing kanamycin. On performing PCR based replicon typing, it was observed that in all the isolates 16SrRNAmethyl transferase genes with coexisting ESBLs and carbapenemases were carried within I1 Inc. type plasmid.

\section{MLST analysis}

While analysing multilocus sequence typing data it was found that E.coli isolates harbouring $r m t H$, armA and $r m t F$ were of sequence type 4410. Additionally ST 1341 was found to carry rmtF gene. E.coli ST3906 was carrying $r m t C$ and $r m t D$. Isolates harbouring $r m t B, r m t G$, rmtEand $n p m A$ gene were found to be of unknown Sequence types.

\section{Discussion}

Aminoglycosides are potent and broad spectrum antibiotic which is often used to treat hospital acquired infections. Probably, this is the reason why different aminoglycoside modifying enzymes (AMEs) and methyl 
Table 2 PCR assay results of $16 S$ rRNA methyltransferase genes with co-existing ESBLs and Carbapenemase

\begin{tabular}{|c|c|c|c|c|c|c|}
\hline SI. no & $16 \mathrm{~S}$ rRNA methyltransferase genes harbouring isolates & Co-existing ESBLs & & Co- existing $\mathrm{c}$ & rbapenemase & Sequence Types \\
\hline 1 & $r m t C(n=12)$ & CTX-M-15(n=9) & - & $\operatorname{NDM}(n=1)$ & - & ST3906 \\
\hline 2 & $\operatorname{armA}(n=11)$ & CTX-M-15(n=3) & $\operatorname{VEB}(n=1)$ & $\operatorname{NDM}(n=2)$ & OXA-48 $(n=1)$ & ST4410 \\
\hline 3 & $r m t D(n=9)$ & CTX-M-15(n=5) & - & $\operatorname{NDM}(n=2)$ & OXA-48 $(n=1)$ & ST3906 \\
\hline 4 & $r m t F(n=8)$ & CTX-M-15(n=2) & - & $\operatorname{NDM}(n=1)$ & OXA-48 $(n=1)$ & ST1341 \\
\hline 5 & $r m t B(n=6)$ & CTX-M-15(n=3) & - & $\operatorname{NDM}(n=2)$ & OXA-48 $(n=2)$ & Unknown \\
\hline 6 & $n p m A(n=5)$ & CTX-M-15(n=2) & $\operatorname{VEB}(n=1)$ & $\operatorname{NDM}(n=1)$ & - & Unknown \\
\hline 7 & $r m t H(n=4)$ & CTX-M-15(n=7) & $\operatorname{PER}(n=1)$ & $\operatorname{NDM}(n=3)$ & OXA-48 $(n=1)$ & ST4410 \\
\hline 8 & $r m t E(n=1)$ & CTX-M-15(n= 1) & - & $\operatorname{NDM}(n=2)$ & - & Unknown \\
\hline 9 & $r m t G(n=1)$ & CTX-M-15(n= 1) & - & $\operatorname{NDM}(n=3)$ & OXA-48 $(n=1)$ & Unknown \\
\hline 10 & $\operatorname{armA}+r m t F(n=6)$ & CTX-M-15(n=3) & - & $\operatorname{NDM}(n=1)$ & - & ST4410 \\
\hline 11 & $r m t G+r m t H(n=3)$ & CTX-M-15(n=2) & - & $\operatorname{NDM}(n=1)$ & - & ST4410 \\
\hline 12 & $\operatorname{armA+rmtE}(n=3)$ & CTX-M-15(n=1) & - & $\operatorname{NDM}(n=2)$ & - & ST4410 \\
\hline 13 & $r m t C+r m t D(n=3)$ & CTX-M-15(n=1) & - & - & OXA-48 $(n=1)$ & ST3906 \\
\hline 14 & $\operatorname{armA+rmtA}(n=2)$ & CTX-M-15(n= 1) & - & $\operatorname{NDM}(n=1)$ & - & ST4410 \\
\hline 15 & $\operatorname{armA}+r m t F+r m t C+r m t D(n=3)$ & CTX-M-15(n=1) & - & $\operatorname{NDM}(n=1)$ & OXA-48 $(n=1)$ & ST3906 \\
\hline
\end{tabular}

transferase enzymes are evolved in bacteria that are propagated and maintained among strains in hospital environment. These strains are needed to be detected and dissected in order to track their movement and potential lateral transfer of resistance determinants. The first $16 \mathrm{~s}$ rRNA methyl transferase gene $\operatorname{arm} A$ was reported from Poland and subsequently $r m t A$ gene was discovered from Japan [24]. Since then, it is reported from different part of the world. In India six variants are reported till date [2-4]. A recent study from Nepal has showed coexistence of DIM-1, NDM-1 and VIM-2 with rmtB4 and rmtF2 [25] where two novel variants of resistance genes were identified. In the current study we found ten different types of acquired 16S rRNA methyltransferase types along with CTX-M-15, VEB, PER, NDM and OXA-48 like betalactamases. Presence of co-existing ESBLs and carbapenemases are quite alarming as these would severely compromise combination therapy.

In our setting acquired $16 \mathrm{~S}$ rRNA methyltransferase genes along with other beta-lactamase genes were found to be associated with Inc. I1 group of plasmid. Therefore, this broad host range plasmid was the genetic vehicle for horizontal transfer of aminoglycoside, cephalosporin and carbapenem resistance in this part of the India. In the current study three sequence types of $E$. coli were responsible for expansion and propagation of this multidrug resistant trait in this setting. In a similar study from US E.coli ST448 was found to harbour rmtE1 type along with extended spectrum beta-lactamases [26]. However, the three sequence types of $E$. coli obtained in this study is not reported elsewhere to be associated with aminoglycoside resistance.

\section{Conclusions}

The expansion of the three sequence types of E.coli ST4410, ST1341 and ST3906 appear to be potential risky local sequence types and of clinical concern that may complicate infection control program. Therefore, further investigations should be undertaken to trace the origin and evolution of these clones thereby preventing or atleast slowing down their spread.

\section{Supplementary information}

Supplementary information accompanies this paper at https://doi.org/10. 1186/s12879-020-05264-4.

\section{Additional file 1}

\section{Abbreviations}

MLST: Multilocus sequence typing; ESBL: Extended Spectrum Beta-lactamase; MIC: Minimum inhibitory concentration

\section{Acknowledgements}

The authors would like to acknowledge Jawaharlal Nehru Memorial Trust for providing scholarship to Jayalaxmi Wangkheimayum and DBT project BT/ PR24255/NER/95/716/2017 dated 05.10.2018.

\section{Authors' contributions}

JW performed the experimental work, data collection and analysis and prepared the manuscript. AB Supervised the research work and participated in designing the study and drafting the manuscript. MB have done data analysis. BJD \& MS participated in sample collection and part of experiments. DD participated in experiment designing and manuscript correction. All authors read and approved the final manuscript.

\section{Funding}

JNMF scholarship were awarded to JayalaxmiWangkheimayum Vide letter no; SU-1/068/2018-19/89 dated December 42,017 and DBT project BT/PR24255/ NER/95/716/2017 dated 05.10.2018 and ICMR SRF to JayalaxmiWangkheimayum vide letter no; AMR/Fellowship/19/2019-ECD-II/ID No. 2019-3677 dated 21.08.2019. 


\section{Availability of data and materials}

Available on request as per Government of India regulations.

\section{Ethics approval and consent to participate}

The study was approved by Institutional ethical committee of Assam University, Silchar and Institutional ethical committee, Silchar Medical College and Hospital. Informed consent from patient was obtained.

\section{Consent for publication}

N/A

\section{Competing interests}

None to declare.

\section{Author details}

'Department of Microbiology, Assam University Silchar, Silchar, India. ${ }^{2}$ Department of Microbiology, Silchar Medical College and Hospital, Silchar, India.

Received: 30 April 2020 Accepted: 16 July 2020

Published online: 18 August 2020

\section{References}

1. Vakulenko SB, Mobashery S. Versatility of aminoglycosides and prospects for their future. Clin Microbiol Rev. 2003:16:430-50 https://doi.org/10.1128/CMR. 16.3 .

2. Rahman M, Prasad KN, Pathak A, Pati BK, Singh A, Ovejero CM, Ahmad S, Gonzalez-Zorn B. RmtC and RmtF 16S rRNAMethyltransferase in NDM-1Producing Pseudomonas aeruginosa. Emerg Infect Dis. 2015;21(11). https:// doi.org/10.3201/eid2111.150271 www.cdc.gov/eid.

3. Gopalakrishnan S, Kamalanathan A, Rajan S, Bhagat VM, Ali MKS. Emergence of armA and rmtB genes among VIM, NDM, and IMP metallo- $\beta$-lactamase producing multidrug-resistant Gram-negative pathogens. Acta Microbiol Immunol Hung. 2018:65(1):107-18 https://doi.org/10.1556/030.64.2017.027.

4. Wangkheimayum J, Paul D, Dhar D, Nepram R, Chetri S, Bhowmik D, Chakravarty A. Amitabha Bhattacharjee; Occurrence of Acquired 16S rRNAMethyltransferase-Mediated Aminoglycoside Resistance in Clinical Isolates of Enterobacteriaceaewithin a Tertiary Referral Hospital of Northeast India. Antimicrob Agents Chemother. 2017;61:e01037-16 https://doi.org/10. 1128/AAC.01037-16.

5. Bogaerts P, Galimand M, Bauraing C, Deplano A, Vanhoof R, De Mendonca R, Rodriguez-Villalobos H, Struelens M, Glupczynski Y. Emergence of ArmA and RmtB aminoglycoside resistance $16 \mathrm{~S}$ rRNAmethylases in Belgium. J Antimicrob Chemother. 2007;59:459-64 https://doi.org/10.1093/jac/dkl527.

6. Chen L, Chen ZL, Liu JH, Zeng ZL, Ma JY, Jiang HX. Emergence of rmtBmethylase-producing Escherichia coli and Enterobacter cloacae isolates from pigs in China. J Antimicrob Chemother. 2007:59:880-5 https://doi.org/ 10.1128/AAC.00748-08

7. Galimand M, Courvalin P, Lambert T. Plasmid-mediated highlevel resistance to aminoglycosides in Enterobacteriaceae due to $16 \mathrm{~S}$ rRNA methylation. Antimicrob Agents Chemother. 2003;47:2565-71 https://doi.org/10.1128/ AAC.47.8.

8. Lee H, Yong D, Yum JH, Roh KH, Lee K, Yamane K, Arakawa Y, Chong Y. Dissemination of $16 \mathrm{~S}$ rRNAmethylase-mediated highly amikacin-resistant isolates of Klebsiellapneumoniae and Acinetobacterbaumannii in Korea. Diagn Microbiol Infect Dis. 2006;56:305-12 https://doi.org/10.1016/j.diagmicrobio. 2006.05.002

9. Yamane K, Wachino J, Suzuki S, Kato H, Shibayama K, Kimura K, Kumiko K, Satoshi I, Ozawa Y, Toshifumi K, Arakawa Y. 16S rRNAmethylase-producing, gram-negative pathogens, Japan. Emerg Infect Dis. 2007;13:642-6.

10. Yu YS, Zhou H, Yang Q, Chen YG, Li LJ. Widespread occurrence of aminoglycoside resistance due to armAmethylase in imipenem-resistant Acinetobacterbaumannii isolates in China. J Antimicrob Chemother. 2007:60: 454-5 https://doi.org/10.1093/jac/dkm208

11. Wachino J-I, Yamane K, Kimura K, Shibata N, Suzuki S, Ike Y, Arakawa Y, et al. Antimicrob Agents Chemother. 2006;50:3212-5 https://doi.org/10.1128/AAC. 00550-06.

12. Clinical and Laboratory Standards Institute. Performance standards for antimicrobial susceptibility testing; twenty-first informational supplement. M100-S27. Wayne: Clinical and Laboratory Standards Institute; 2017.
13. Wu Q, Zhang Y, Han L, Sun J, Ni Y. Plasmid-mediated $16 \mathrm{~S}$ rRNAmethylases in aminoglycoside-resistant Enterobacteriaceaeisolates in Shanghai, China. Antimicrob Agents Chemother. 2009;53:271-2. https://doi.org/10.1128/AAC. 00748-08.

14. Davis MA, Baker KN, Orfe LH, et al. Discovery of a gene conferring multipleaminoglycoside resistance in Escherichia coli. Antimicrob Agents Chemother. 2010;54:2666-9.

15. Hidalgo L, Hopkins KL, Gutierrez B, Ovejero CM, Shukla S, Douthwaite S, et al. Association of the novel aminoglycoside resistance determinant RmtF with NDM carbapenemase in Enterobacteriaceae isolated in India and the UK. J Antimicrob Chemother. 2013;68:1543-50 https://doi.org/10.1093/jac/ dkt078.

16. Bueno MF, Francisco GR, O'Hara JA, de Oliveira GD, Doi Y. Coproduction of $16 \mathrm{~S}$ rRNAmethyltransferaseRmtD or RmtG with KPC-2 and CTX-M group extended-spectrum $\beta$-lactamases in Klebsiellapneumoniae. Antimicrob Agents Chemother. 2013;57:2397-400. https://doi.org/10.1128/AAC.02108-12.

17. O'Hara JA, McGann P, Snesrud EC, Clifford RJ, Waterman PE, Lesho EP, et al. Novel $16 \mathrm{~S}$ rRNAmethyltransferaseRmtH produced by Klebsiellapneumoniaeassociated with war-related trauma. Antimicrob Agents Chemother. 2013;57:2413-6 https://doi.org/10.1128/AAC.00266-13.

18. Bert F, Branger C, Zechovsky NL. Identification of PSE and OXA B-lactamase genes in Pseudomonas aeruginosa using PCR-restriction fragment length polymorphism. J Antimicrob Chemother. 2002;50:11-8 https://doi.org/10. 1093/jac/dkf069.

19. Colom K, Perez J, Alonso R, Aranguiz AF, Larino E, Cisterna R. Simple and reliable multiplex PCR assay for detection of blaTEM, blaSHV and blaOXA-1 genes in Enterobacteriaceae. FEMS Microbiol Lett. 2003;223:147-51 https:// doi.org/10.1016/S0378-1097(03)00306-9.

20. Lee S, Park YJ, Kim M, Lee HK, Han K, Kang CS. Prevalence of ambler class a and D B-lactamases among clinical isolates of Pseudomonas aeruginosa in Korea. J Antimicrob Chemother. 2005;56:122-7.

21. Yong D, Toleman MA, Giske CG, Cho HS, Sundman K, Lee K. Characterization of a new Metallo- $\beta$-lactamase gene, blaNDM-1, and a novel erythromycin esterase gene carried on a unique genetic structure in Klebsiellapneumoniae sequence type 14 from India. Antimicrob Agents Chemother. 2009:53:5046-54 https://doi.org/10.1128/AAC.00774-09.

22. Dallenne C, Costa AD, Decre D, Favier C, Arlet G. Development of a set of multiplex PCR assays for the detection of genes encoding important $\beta$ lactamases in Enterobacteriaceae. J Antimicrob Chemother. 2010;65:490-5 https://doi.org/10.1093/jac/dkp498.

23. Carattoli A, Bertini A, Villa L, Falbo V, Hopkins KL, Threlfall EJ. Identification of plasmids by PCR-based replicon typing. J Microbiol Methods. 2005;63:21928 https://doi.org/10.1016/j.mimet.2005.03.018.

24. Doi Y, Arakawa Y. 165 ribosomal RNA methylation: emerging resistance mechanism against aminoglycosides. Clin Infect Dis. 2007:45:88-94.

25. Tada T, Shimada K, Satou K, Hirano T, Pokhrel BM, Sherchand J, Kirikae T. Metallo- $\beta$-lactamases (DIM-1, NDM-1, VIM-2) and a $16 \mathrm{~S}$ rRNAmethyltransferase (RmtB4, RmtF2) producing Pseudomonas aeruginosa in Nepal. Antimicrob Agents Chemother. https://doi.org/10.1128/AAC 00694-17.

26. Li B, Pacey MP, Do Y. Chromosomal 16S Ribosomal RNA Methyltransferase RmtE1 in Escherichia coli Sequence Type 448. Emerg Infect Dis. 2017;23(5). https://doi.org/10.3201/eid2305.162000 www.cdc.gov/eid.

\section{Publisher's Note}

Springer Nature remains neutral with regard to jurisdictional claims in published maps and institutional affiliations. 